\title{
Do Wetting Agents Influence Golf Ball Roll Distance?
}

\author{
Travis Wayne Shaddox ${ }^{1}$ and Joseph Bryan Unruh ${ }^{2}$
}

AdDitional INDEX wORDs. Cynodon dactylon $\times$ Cynodon transvaalensis, firmness, putting green, 'TifEagle' hybrid bermudagrass, turfgrass

SUMMARY. Wetting agents are commonly applied to golf putting greens to manage soil moisture. Speculation has arisen regarding the influence of wetting agents on golf ball roll distance. The objective of this study was to determine the influence of wetting agents on golf ball roll distance, putting green surface firmness, and volumetric water content in sand-based putting greens. This study was conducted during the 2018 growing season in Jay, FL and Ft. Lauderdale, FL on 'TifEagle' hybrid bermudagrass (Cynodon dactylon $\times$ C. transvaalensis) putting greens. Treatments were applied to plots $(2 \times 3 \mathrm{~m})$ in a randomized complete block design using four replications, and included seven wetting agents and an untreated turfgrass control. The study area was irrigated at $80 \%$ of the previous week's reference evapotranspiration. Ball roll distance, firmness, and volumetric water content (VWC) were recorded weekly and pooled by month. Wetting agents did not lead to an increase in ball roll distance, firmness, or VWC during any month in Jay or Ft. Lauderdale. Inversely, in Jay, polyoxyalkylene polymer resulted in decreased surface firmness during October and November compared with untreated turfgrass. VWC was reduced as a result of some wetting agents in Ft. Lauderdale in February, September, November, and December, and resulted in no influence on VWC in Jay. The coefficients of determination of surface firmness and ball roll distance in Jay and Ft. Lauderdale were significant $(P<0.001)$ and were 0.12 and 0.08 , respectively. This indicates that ball roll distance can increase as surfaces become firmer. However, this study found no evidence that wetting agents increase ball roll distance on sand-based putting greens.

$\mathrm{W}$ etting agents are commonly used on golf course bermudagrass (Cynodon sp.) putting greens to manage soil moisture. Turfgrass quality on putting greens can be restricted if hydrophobic conditions arise, and wetting agents have been used to alleviate this hydrophobicity and increase turfgrass quality (Aamlid et al., 2009). However, some wetting agent manufacturers posit wetting agents also increase putting green surface firmness and ball roll distance (commonly referred to as putting green speed). These claims may originate from the assumption

Received for publication 14 Jan. 2020. Accepted for publication 3 Apr. 2020

Published online 30 April 2020.

${ }^{1}$ Department of Plant and Soil Sciences, University of Kentucky, 417 Plant and Soil Science Building, 1405 Veterans Drive, Lexington, KY 40546

${ }^{2}$ West Florida Research and Education Center, University of Florida, 4235 Experiment Drive Jay, FL 32565

T.W.S. is the corresponding author. E-mail: Shaddox@ uky.edu.

This is an open access article distributed under the CC BY-NC-ND license (https://creativecommons.org/ licenses/by-nc-nd/4.0/).

https://doi.org/10.21273/HORTTECH04576-20 that wetting agents have differing abilities to move water deeper into the root zone, which may, in turn, result in a drier, firmer surface. This has resulted in many turfgrass managers applying wetting agents not only to manage moisture, but also to manage golf ball roll distances without any confirmatory evidence. Because wetting agents can account for a substantial portion of a turfgrass manager's budget, it is essential that the influence wetting agents have on golf ball roll distance be determined.

Some researchers report wetting agents influence the VWC of sand-based putting greens, whereas others report no influence. Soldat et al. (2010) reported that wetting agents resulted in lower VWC than well-irrigated plots during both years of their 2-year study. However, Soldat et al. (2010) reported the distribution uniformity was greater in wetting agent-treated plots than in the reduced-irrigation control plot, which indicates the volume of water near the putting green surface may be reduced by using wetting agents but the remaining water is distributed more uniformly when compared with reduced-irrigation plots. Similar results have been reported for warm-season turfgrasses. Schiavon et al. (2014) investigated the influence of wetting agents on 'Princess 77' bermudagrass (Cynodon dactylon) maintained under deficit irrigation and reported that soil moisture was more uniform as a result of one of the two wetting agents tested during their 3-year study. In south Florida, Cisar et al. (2000) reported that soil water repellency of a 'Tifdwarf' hybrid bermudagrass (C. dactylon $\times$ C. transvaalensis) putting green was reduced following the application of wetting agents. Other studies have also provided similar moisture uniformity results when using wetting agents on sand-based putting greens (Aamlid et al., 2009; Kostka et al., 2008). However, Bauer et al. (2017) investigated the influence of 13 wetting agents or wetting agent combinations on an 88:12 (sand:peat) putting green in Minnesota and reported that the VWC of the top $12 \mathrm{~cm}$ was not influenced by wetting agents when compared with untreated turfgrass on any rating date during the 2-year study. Bauer et al. (2017) speculated that the lack

\begin{tabular}{llll}
\hline $\begin{array}{l}\text { Units } \\
\begin{array}{l}\text { To convert U.S. to SI, } \\
\text { multiply by }\end{array}\end{array}$ & U.S. unit & SI unit & $\begin{array}{l}\text { To convert SI to U.S., } \\
\text { multiply by }\end{array}$ \\
\hline 29.5735 & $\mathrm{fl} \mathrm{oz}$ & $\mathrm{mL}$ & 0.0338 \\
0.0731 & $\mathrm{fl} \mathrm{oz} / \mathrm{acre}$ & $\mathrm{L} \cdot \mathrm{ha}^{-1}$ & 13.6840 \\
0.3048 & $\mathrm{ft}$ & $\mathrm{m}$ & 3.2808 \\
9.3540 & gal/acre & $\mathrm{L} \cdot \mathrm{ha}^{-1}$ & 0.1069 \\
2.54 & inch $(\mathrm{es})$ & $\mathrm{cm}$ & 0.3937 \\
25.4 & inch $(\mathrm{es})$ & $\mathrm{mm}$ & 0.0394 \\
1.1209 & lb/acre & $\mathrm{kg} \cdot \mathrm{ha}^{-1}$ & 0.8922 \\
1 & meq/100 $\mathrm{cm}$ & $\mathrm{cmol} \cdot \mathrm{kg}^{-1}$ & 1 \\
1.6093 & mile $(\mathrm{s})$ & $\mathrm{km}$ & 0.6214 \\
1 & $\mathrm{mmho} / \mathrm{cm}$ & $\mathrm{mS} \cdot \mathrm{cm}^{-1}$ & 1 \\
28.3495 & $\mathrm{oz}$ & $\mathrm{g}$ & 0.0353 \\
1 & $\mathrm{ppm}$ & $\mathrm{mg} \cdot \mathrm{kg}^{-1}$ & 1 \\
$\left({ }^{\circ} \mathrm{F}-32\right) \div 1.8$ & ${ }^{\circ} \mathrm{F}$ & ${ }^{\circ} \mathrm{C}$ & $\left({ }^{\circ} \mathrm{C} \times 1.8\right)+32$ \\
\end{tabular}


Table 1. Active ingredient, manufacture, and application rate of wetting agents applied to 'TifEagle' hybrid bermudagrass at Ft. Lauderdale, FL and Jay, FL in 2018.

\begin{tabular}{|c|c|c|c|}
\hline Treatment & Active ingredient & Manufacturer & $\begin{array}{l}\text { Active ingredient application } \\
\text { rate }\left(\mathrm{L} \cdot \mathrm{ha}^{-1}\right)^{\mathrm{z}}\end{array}$ \\
\hline Untreated & - & - & - \\
\hline Aqua-Aid & Nonionic polyol & Aqua-Aid, Rocky Mountain, NC & 2.4 \\
\hline Lesco Wet & Nonionic surfactant & Lesco, Cleveland, $\mathrm{OH}$ & 11.1 \\
\hline Hydro-90 & Alkoxylated polyol & Hocking International Laboratories & 19.0 \\
\hline Magnus & Polypropylene glycol & Precision Laboratories, Waukegan, IL & 12.7 \\
\hline
\end{tabular}

${ }^{\mathrm{z}} \mathrm{l} \mathrm{L} \cdot \mathrm{ha}^{-1}=0.1069 \mathrm{gal} / \mathrm{acre}$.
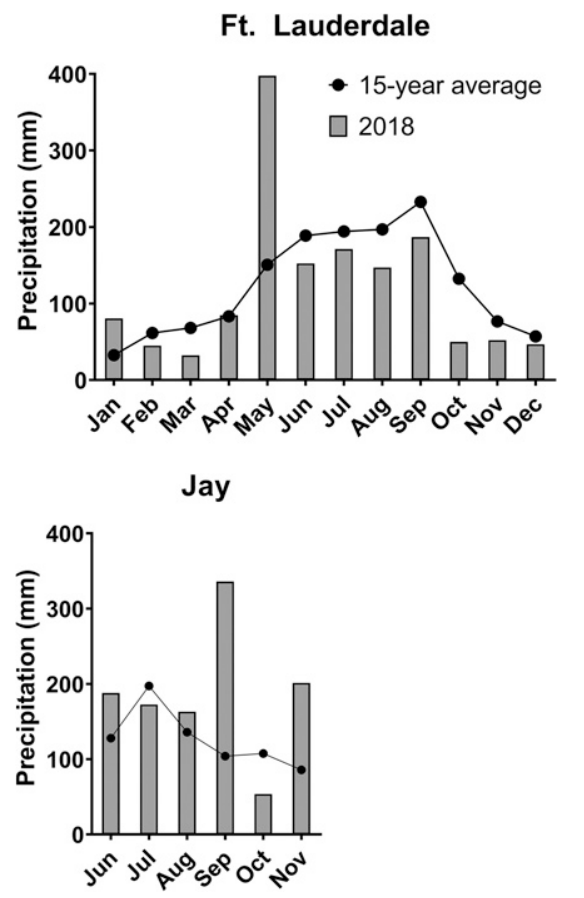

Fig. 1. Precipitation for 2018 and 15-year average precipitation by month at Ft. Lauderdale, FL and Jay, $\mathrm{FL} ; 1 \mathrm{~mm}=0.0394$ inch .

of difference in VWC may have been a result of the lack of water repellency over the trial area.

Soil VWC has been correlated with putting green surface firmness. Linde et al. (2011) measured VWC and putting green surface firmness on 50 golf courses in New Zealand and reported the relationship was significant $(P<0.001)$ and linear, with a coefficient of determination of 0.44. When they measured VWC and surface firmness from individual golf courses, the relationship was also significant $(P<0.001)$, but the variability resulted in a range of coefficients of determination (0.19-0.7). Linde et al. (2011) speculated that the variability could be a result of a number of factors unrelated to VWC, such as turfgrass species, soil texture, and soil bulk density. Other researchers have also reported similar results. Baker et al. (1996) sampled 147 putting greens on 74 golf courses in Great Britain and reported a weak relationship $\left(r^{2}=0.28\right)$ between VWC and surface firmness.

Ball roll distance is an important and commonly measured variable of putting greens. As a matter of perspective, amateur golfers may struggle if the ball roll distance is greater than $300 \mathrm{~cm}$, whereas professional golfers commonly play on putting greens with ball roll distances greater than $365 \mathrm{~cm}$. Thus, ball roll distance is an important variable that superintendents must manage. Because prior research has indicated that wetting agents influence VWC, and VWC and surface firmness are correlated, speculation exists that wetting agents, in turn, influence golf ball roll distance. Munoz (2016) claimed that the application of a wetting agent will result in a "firm and fast" surface as a result of the increased downward movement of moisture. McCarty (2016) classified wetting agents as soil penetrants and soil water retainers, and identified soil penetrants as wetting agents that move water rapidly through the soil profile and provide uniform moisture distribution leading to a "firm and fast" surface. The implication that drier, firmer surfaces lead to greater ball roll distances may be accurate, but evidence supporting this assumption is lacking.

Each of the aforementioned studies measured the influence of wetting agents on various soil and turfgrass dynamics. However, none of the studies measured the influence of wetting agents on golf ball roll distance. Therefore, the hypotheses of this study were that wetting agents influence the VWC, increase surface firmness, and increase golf ball roll distance on sand-based putting greens.

\section{Materials and methods}

This study was conducted at the University of Florida's Research and Education Centers in Jay, FL (lat. $30^{\circ} 46^{\prime} \mathrm{N}$, long. $87^{\circ} 08^{\prime} \mathrm{W}$ ), and in Ft. Lauderdale, FL (lat. $29^{\circ} 24^{\prime} \mathrm{N}$, long. $\left.82^{\circ} 10^{\prime} \mathrm{W}\right)$. The study was conducted during the 2018 growing season at each location, which was from 1 June to 29 Nov. in Jay, and from 1 Jan. to 31 Dec. in Ft. Lauderdale.

Plots $(2 \times 3 \mathrm{~m})$ were arranged in a randomized complete block design on 'TifEagle' hybrid bermudagrass grown on 90:10 (sand:peat) and 80:20 root zones in Ft. Lauderdale and Jay, respectively. Each putting green was constructed according to U.S. Golf Association specifications (U.S. Golf Association, 2018). The putting green in Jay was established for more than 5 years, whereas the Ft. Lauderdale putting green was established in 2016. Treatments are described in Table 1 and were applied in Jay on 5 June, 5 July, 30 July, 29 Aug., 25 Sept., 17 Oct., and 16 Nov; and in Ft. Lauderdale on 8 Jan., 5 Feb., 5 Mar., 2 Apr., 30 Apr., 4 June, 2 July, 30 July, 27 Aug., 1 Oct., 5 Nov., and 3 Dec. Treatments were applied in 4-week intervals according to the manufacturer's highest recommended 30-d interval rate. Treatments were dissolved in water $\approx \mathrm{l} \mathrm{h}$ before application and were applied uniformly across each plot using a carbon dioxide backpack sprayer set to deliver a volume of $750 \mathrm{~L} \cdot \mathrm{ha}^{-1}$. After treatment application, irrigation 
delivered $5 \mathrm{~mm}$ of water to move the treatments into the soil.

Soil VWC, surface firmness, and ball roll distance were recorded within a 2 -h period each week and pooled by month. Soil VWC in the top 1.5 inches was measured using time domain reflectometry via a soil probe

Table 2. Chemical properties of putting green root zones at Jay, FL and Ft. Lauderdale, FL.

\begin{tabular}{lrr}
\hline Parameter & Jay & Ft. Lauderdale \\
\hline Mehlich III extractable $\left(\mathrm{mg} \cdot \mathrm{kg}^{-1}\right)^{\mathrm{z}}$ & 8.5 & 69.0 \\
Potassium & 5.5 & 21.0 \\
Calcium & 129.5 & 498.5 \\
Magnesium & 22.5 & 28.5 \\
Zinc & 3.1 & 4.6 \\
$\mathrm{CEC}\left(\mathrm{cmol} \cdot \mathrm{kg}^{-1}\right)^{\mathrm{y}}$ & 1.0 & 1.6 \\
$\mathrm{pH}_{\mathrm{KCl}}^{\mathrm{x}}$ & 4.4 & 6.5 \\
$\mathrm{EC}\left(\mathrm{mS} \cdot \mathrm{cm}^{-1}\right)^{\mathrm{w}}$ & 0.1 & 0.1 \\
$\mathrm{OM}(\%)^{\mathrm{v}}$ & 0.7 & 0.8 \\
\hline
\end{tabular}

${ }^{\mathrm{z}}$ Nutrients extracted using the Mehlich III extractant; $1 \mathrm{mg} \cdot \mathrm{kg}^{-1}=1 \mathrm{ppm}$.

${ }^{y}$ Cation exchange capacity by ammonium acetate, $\mathrm{pH} 7.0 ; 1 \mathrm{cmol} \cdot \mathrm{kg}^{-1}=1 \mathrm{meq} / 100 \mathrm{~g}$.

${ }^{x} 1: 1$ (soil: 1 m potassium chloride).

${ }^{\mathrm{w}}$ Electrical conductivity; $1 \mathrm{mS} \cdot \mathrm{cm}^{-1}=1 \mathrm{mmho} / \mathrm{cm}$.

${ }^{\mathrm{v}}$ Organic matter by weight loss on ignition.
[FieldScout TDR 350 (Ft. Lauderdale), FieldScout TDR 300 (Jay); Spectrum Technologies, Aurora, IL] with 1.5 -inch rods. Surface firmness was measured using an impact hammer (FieldScout TruFirm, Spectrum Technologies). Soil VWC and firmness were recorded as the average of three random locations inside each plot. Surface firmness data were transformed by subtracting the instrument reading from the maximum possible reading ( 1.5 inches). Ball roll distance was measured using the half-distance setting of a stimpmeter (U.S. Golf Association, Manchester, CT). Ball roll distance was recorded as the average of three balls rolled in the same direction and three balls rolled in the opposite direction. Tropical storm Gordan made landfall 90 miles west of Jay, FL on 4 Sept. As

Table 3. Putting green volumetric water content, surface firmness, and ball roll distance as influenced by wetting agents applied to 'TifEagle' hybrid bermudagrass at Ft. Lauderdale, FL in 2018.

\begin{tabular}{|c|c|c|c|c|c|c|c|c|c|c|c|c|}
\hline \multirow[b]{2}{*}{ Treatment $^{\mathrm{z}}$} & Jan. & Feb. & Mar. & Apr. & May & June & July & Aug. & Sept. & Oct. & Nov. & Dec. \\
\hline & \multicolumn{12}{|c|}{ - } \\
\hline Untreated & 19.4 aby & $20.3 \mathrm{a}$ & 23.3 & 26.2 & 29.3 & 29.4 & $23.8 \mathrm{ab}$ & 24.5 & $27.2 \mathrm{a}$ & 28.0 & $25.7 \mathrm{a}$ & $26.4 \mathrm{a}$ \\
\hline Aqua-Aid & $18.4 \mathrm{ab}$ & $19.2 \mathrm{ab}$ & 21.6 & 24.8 & 28.5 & 27.5 & $22.9 \mathrm{ab}$ & 23.0 & $23.8 \mathrm{~b}$ & 26.4 & $24.2 \mathrm{ab}$ & $25.0 \mathrm{ab}$ \\
\hline Fleet & $17.9 \mathrm{~b}$ & $18.0 \mathrm{~b}$ & 21.9 & 25.0 & 26.7 & 26.8 & $22.6 \mathrm{ab}$ & 21.7 & $23.3 \mathrm{~b}$ & 23.9 & $21.6 \mathrm{~b}$ & $23.7 \mathrm{~b}$ \\
\hline Hydro-90 & $18.2 \mathrm{ab}$ & $18.3 \mathrm{~b}$ & 22.0 & 24.8 & 28.1 & 28.0 & $22.4 \mathrm{ab}$ & 22.3 & $24.2 \mathrm{ab}$ & 25.0 & $22.6 \mathrm{ab}$ & $25.1 \mathrm{ab}$ \\
\hline Lesco-Wet & $20.0 \mathrm{a}$ & $20.3 \mathrm{a}$ & 23.7 & 26.9 & 29.1 & 29.3 & $24.8 \mathrm{a}$ & 24.1 & $25.2 \mathrm{ab}$ & 27.2 & $24.1 \mathrm{ab}$ & $25.4 \mathrm{ab}$ \\
\hline Magnus & $19.0 \mathrm{ab}$ & $19.7 \mathrm{ab}$ & 23.3 & 26.0 & 29.3 & 28.8 & $23.6 \mathrm{ab}$ & 23.3 & $25.4 \mathrm{ab}$ & 26.2 & $23.5 \mathrm{ab}$ & $24.9 \mathrm{ab}$ \\
\hline Revolution & $18.2 \mathrm{ab}$ & $18.4 \mathrm{~b}$ & 21.5 & 24.7 & 28.2 & 28.0 & $22.1 \mathrm{ab}$ & 21.9 & $23.7 \mathrm{~b}$ & 24.5 & $22.4 \mathrm{ab}$ & $25.3 \mathrm{ab}$ \\
\hline Symphony & $18.7 \mathrm{ab}$ & $18.8 \mathrm{ab}$ & 22.4 & 26.1 & 28.9 & 27.6 & $22.0 \mathrm{~b}$ & 22.9 & $23.3 \mathrm{~b}$ & 25.2 & $22.2 \mathrm{~b}$ & $24.4 \mathrm{~b}$ \\
\hline \multirow[t]{2}{*}{ Significance } & * & $* * *$ & NS & NS & NS & NS & $* *$ & NS & $* *$ & NS & $* *$ & ** \\
\hline & \multicolumn{12}{|c|}{ - } \\
\hline Untreated & 1.07 & 1.01 & 1.05 & 0.99 & 0.96 & 0.98 & 0.97 & 0.95 & 0.97 & 0.94 & 0.91 & 0.94 \\
\hline Aqua-Aid & 1.07 & 1.00 & 1.05 & 1.00 & 0.96 & 0.99 & 0.98 & 0.95 & 0.97 & 0.94 & 0.92 & 0.94 \\
\hline Fleet & 1.07 & 1.01 & 1.05 & 0.99 & 0.95 & 0.99 & 0.98 & 0.96 & 1.00 & 0.96 & 0.92 & 0.94 \\
\hline Hydro-90 & 1.07 & 1.00 & 1.05 & 0.98 & 0.94 & 0.99 & 0.98 & 0.96 & 0.97 & 0.93 & 0.92 & 0.94 \\
\hline Lesco-Wet & 1.07 & 1.01 & 1.04 & 0.99 & 0.95 & 0.98 & 0.97 & 0.94 & 0.95 & 0.93 & 0.92 & 0.95 \\
\hline Magnus & 1.07 & 1.00 & 1.04 & 0.99 & 0.97 & 0.98 & 0.97 & 0.95 & 0.96 & 0.95 & 0.91 & 0.95 \\
\hline Revolution & 1.07 & 1.01 & 1.06 & 0.99 & 0.96 & 1.00 & 0.98 & 0.95 & 0.98 & 0.94 & 0.91 & 0.94 \\
\hline Symphony & 1.06 & 1.01 & 1.06 & 0.98 & 0.95 & 0.99 & 0.97 & 0.95 & 0.95 & 0.94 & 0.91 & 0.94 \\
\hline \multirow[t]{2}{*}{ Significance } & NS & NS & NS & NS & NS & NS & NS & NS & NS & NS & NS & NS \\
\hline & \multicolumn{12}{|c|}{ Ball roll distance $(\mathrm{cm})^{\mathrm{x}}$} \\
\hline Untreated & 235 & 230 & 274 & 245 & 214 & 199 & 219 & 218 & 233 & 240 & 238 & 237 \\
\hline Aqua-Aid & 236 & 230 & 273 & 246 & 213 & 196 & 226 & 221 & 232 & 242 & 239 & 237 \\
\hline Fleet & 246 & 233 & 275 & 251 & 208 & 198 & 221 & 225 & 232 & 244 & 235 & 237 \\
\hline Hydro-90 & 248 & 235 & 271 & 244 & 212 & 197 & 219 & 219 & 234 & 239 & 239 & 235 \\
\hline Lesco-Wet & 238 & 237 & 281 & 248 & 219 & 202 & 223 & 224 & 233 & 245 & 240 & 241 \\
\hline Magnus & 246 & 231 & 275 & 249 & 217 & 201 & 222 & 219 & 234 & 244 & 239 & 240 \\
\hline Revolution & 243 & 234 & 273 & 248 & 216 & 198 & 219 & 224 & 236 & 242 & 236 & 237 \\
\hline Symphony & 250 & 227 & 270 & 244 & 212 & 199 & 221 & 222 & 237 & 245 & 240 & 245 \\
\hline Significance & NS & NS & NS & NS & NS & NS & NS & NS & NS & NS & NS & NS \\
\hline
\end{tabular}


Table 4. Putting green volumetric water content, surface firmness, and ball roll distance as influenced by wetting agents applied to 'TifEagle' hybrid bermudagrass at Jay, FL in 2018.

\begin{tabular}{|c|c|c|c|c|c|c|}
\hline \multirow[b]{2}{*}{ Treatment $^{\mathrm{z}}$} & June & July & Aug. & Sept. & Oct. & Nov. \\
\hline & \multicolumn{6}{|c|}{ - } \\
\hline Untreated & 39.9 & 36.3 & 41.7 aby & $38.3 \mathrm{ab}$ & $41.5 \mathrm{ab}$ & 40.9 \\
\hline Aqua-Aid & 39.8 & 37.8 & $42.8 \mathrm{a}$ & $41.5 \mathrm{a}$ & $43.3 \mathrm{a}$ & 42.8 \\
\hline Fleet & 36.2 & 33.7 & $37.3 \mathrm{~b}$ & $37.0 \mathrm{ab}$ & $39.3 \mathrm{bc}$ & 40.8 \\
\hline Hydro-90 & 39.6 & 37.0 & $40.7 \mathrm{ab}$ & $37.6 \mathrm{ab}$ & $40.3 \mathrm{abc}$ & 41.1 \\
\hline Lesco-Wet & 35.2 & 34.3 & $36.3 \mathrm{~b}$ & $36.3 \mathrm{ab}$ & $36.8 c$ & 38.0 \\
\hline Magnus & 38.0 & 36.7 & $40.8 \mathrm{ab}$ & $38.9 \mathrm{ab}$ & $41.4 \mathrm{ab}$ & 40.3 \\
\hline Revolution & 38.3 & 34.6 & $39.9 \mathrm{ab}$ & $36.8 \mathrm{ab}$ & $39.7 \mathrm{abc}$ & 38.4 \\
\hline Symphony & 36.4 & 35.1 & $39.0 \mathrm{ab}$ & $35.3 \mathrm{~b}$ & $37.4 \mathrm{bc}$ & 37.5 \\
\hline \multirow[t]{2}{*}{ Significance } & NS & NS & $* * *$ & * & $* * *$ & NS \\
\hline & \multicolumn{6}{|c|}{ - Firmness (inch) $)^{\mathrm{x}}$} \\
\hline Untr & $0.84 \mathrm{ab}$ & 0.84 & $0.83 \mathrm{ab}$ & 0.83 & $0.85 \mathrm{a}$ & $0.90 \mathrm{a}$ \\
\hline Aqua-Aid & $0.86 \mathrm{ab}$ & 0.86 & $0.84 \mathrm{a}$ & 0.83 & $0.86 \mathrm{a}$ & $0.88 \mathrm{ab}$ \\
\hline Fleet & $0.87 \mathrm{a}$ & 0.86 & $0.84 \mathrm{a}$ & 0.83 & $0.84 \mathrm{ab}$ & $0.87 \mathrm{ab}$ \\
\hline Hydro-90 & $0.85 \mathrm{ab}$ & 0.86 & $0.82 \mathrm{ab}$ & 0.83 & $0.85 \mathrm{a}$ & $0.86 \mathrm{ab}$ \\
\hline Lesco-Wet & $0.86 \mathrm{ab}$ & 0.86 & $0.84 \mathrm{a}$ & 0.84 & $0.85 \mathrm{a}$ & $0.87 \mathrm{ab}$ \\
\hline Magnus & $0.84 \mathrm{ab}$ & 0.86 & $0.84 \mathrm{a}$ & 0.84 & $0.84 \mathrm{ab}$ & $0.86 \mathrm{ab}$ \\
\hline Revolution & $0.86 \mathrm{ab}$ & 0.84 & $0.82 \mathrm{ab}$ & 0.82 & $0.84 \mathrm{ab}$ & $0.86 \mathrm{ab}$ \\
\hline Symphony & $0.83 \mathrm{~b}$ & 0.83 & $0.79 \mathrm{~b}$ & 0.80 & $0.82 \mathrm{~b}$ & $0.83 \mathrm{~b}$ \\
\hline \multirow[t]{2}{*}{ Significance } & ** & NS & $* * *$ & NS & ** & * \\
\hline & \multicolumn{6}{|c|}{ Ball roll distance $(\mathrm{cm})^{\mathrm{x}}$} \\
\hline Untreated & 232 & 246 & 239 & 243 & 267 & 286 \\
\hline Aqua-Aid & 229 & 242 & 233 & 243 & 260 & 276 \\
\hline Fleet & 227 & 241 & 232 & 237 & 259 & 268 \\
\hline Hydro-90 & 231 & 242 & 231 & 233 & 257 & 272 \\
\hline Lesco-Wet & 222 & 240 & 230 & 232 & 255 & 272 \\
\hline Magnus & 225 & 236 & 226 & 233 & 253 & 271 \\
\hline Revolution & 227 & 242 & 237 & 239 & 258 & 266 \\
\hline Symphony & 222 & 233 & 222 & 224 & 245 & 263 \\
\hline Significance & NS & NS & NS & NS & NS & NS \\
\hline
\end{tabular}

${ }^{\mathrm{z}}$ Aqua-Aid (Aqua-Aid, Rocky Mountain, NC), Fleet (Hocking International Laboratories, Sylacauga, AL), Hydro90 (Hocking International Laboratories), Lesco-Wet (Lesco, Cleveland, OH), Magnus (Precision Laboratories, Waukegan, IL), Revolution (Aquatrols, Paulsboro, NJ), Symphony (Hocking International Laboratories).

${ }^{y}$ Within a column, means followed by a common letter are not significantly different according to the TukeyKramer test at the $5 \%$ significance level.

${ }^{x} 1$ inch $=25.4 \mathrm{~mm}, 1 \mathrm{~cm}=0.3937$ inch.

Ns, ${ }^{*},{ }^{* *},{ }^{* *}$ Nonsignificant or significant at $P \leq 0.05,0.01$, or 0.001 , respectively.

a result, data collected on 4 Sept. were omitted from analysis.

Putting greens were maintained according to industry-standard management practices for an average public golf course in Florida. The putting green in Jay was aerified on 20 Apr., whereas the Ft. Lauderdale putting green was aerified on 4 June and 16 Aug. using a tractor-mounted aerifier (2000 Aercore; John Deere, Moline, IL.) with $1 / 4$-inch tines. After each aerification, the cores were removed and the plots were then topdressed using $\mathrm{l} / 4$ inch of sand (Florida Superior Sand, Greenacres, FL). Vertical mowing occurred in Jay on 15 Aug. and 13 Sept., whereas vertical mowing in Ft. Lauderdale occurred on 15 Mar. and 19 July. Turfgrass was mowed 5 to $6 \mathrm{~d}$ each week at a cut height of $3 \mathrm{~mm}$ using a reel mower (Greensmaster 3150; Toro Co., Bloomington, $\mathrm{MN}$ ). Irrigation supplied water to the turfgrass at a volume of $\approx 80 \%$ of the previous week's reference evapotranspiration (ET). The $80 \%$ reference ET threshold was chosen as a level to minimize turfgrass stress without applying excessive water (Carrow, 1995). Irrigation was suspended for $24 \mathrm{~h}$ when rainfall exceeded $6 \mathrm{~mm}$ during any 24-h period. Pesticides were applied as needed to minimize pest damage. Nitrogen $(\mathrm{N})$, phosphorus $(\mathrm{P})$, and potassium $(\mathrm{K})$ were applied using $12 \mathrm{~N}-1.7 \mathrm{P}-9.9 \mathrm{~K}$ at an $\mathrm{N}$ rate of $12 \mathrm{~kg} \cdot \mathrm{ha}^{-1}$ per week from January through December in Ft. Lauderdale and from May through November in Jay. Micronutrients were applied using a micronutrient solution (Harrell's Max Minors; Harrell's, LLC, Lakeland, FL) set to apply iron at a rate of $0.5 \mathrm{~kg} \cdot \mathrm{ha}^{-1}$ per $90 \mathrm{~d}$. Trinexapac-ethyl (Primo Maxx; Syngenta Crop Protection, Greensboro, NC) was applied on 1 June and 3 Aug. in Ft. Lauderdale at a rate of $2 \mathrm{fl} \mathrm{oz} /$ acre.

Soils were analyzed for $\mathrm{P}, \mathrm{K}$, calcium, magnesium, zinc, cation exchange capacity, $\mathrm{pH}$, electrical conductivity, and organic matter (OM) at the soil testing laboratory within the Division of Regulatory Services at the University of Kentucky (Lexington). Mehlich-III analysis followed the procedure described by Mehlich (1984). Soils were pulverized to pass through a 10-mesh sieve, and a 2 -g subsample was placed into a $20-\mathrm{mL}$ centrifuge tube. Twenty milliliters of Mehlich-III extracting solution was added to the tube, and the tube was shaken on a mechanical shaker for $5 \mathrm{~min}$. The resulting suspension was filtered immediately and an aliquot was collected for elemental analysis by inductively coupled plasma optical emission spectrophotometry (Varian Vista-Pro 2003; Agilent Technologies, Santa Clara, CA). Cation exchange capacity was determined using the ammonium acetate ( $\mathrm{pH} 7$ ) method described by the U.S. Department of Agriculture (2004). Electrical conductivity and $\mathrm{pH}$ were measured using a $2: 1$ water:soil mixture and a conductivity meter (model 3100; YIS, Yellow Springs, $\mathrm{OH}$ ), and an automated $\mathrm{pH}$ analyzer (AS-3010D; Labfit, Bayswater, Australia), respectively. OM was measured by loss-on-ignition as described by Nelson and Sommers (1996). Three grams of air-dried soil were placed in $40-\mathrm{mL}$ crucibles and heated to $105^{\circ} \mathrm{C}$ for $24 \mathrm{~h}$. Aliquots were weighed and then ignited in a muffle furnace at $400{ }^{\circ} \mathrm{C}$ for $16 \mathrm{~h}$. The weight of the ignited samples was subtracted from the initial weight and reported as percent OM.

Precipitation data were collected during the duration of the research from an onsite weather network system (University of Florida, 2020), which provided meteorological information in 15-min intervals. Data collection stations were located within $100 \mathrm{~m}$ of the study locations. 


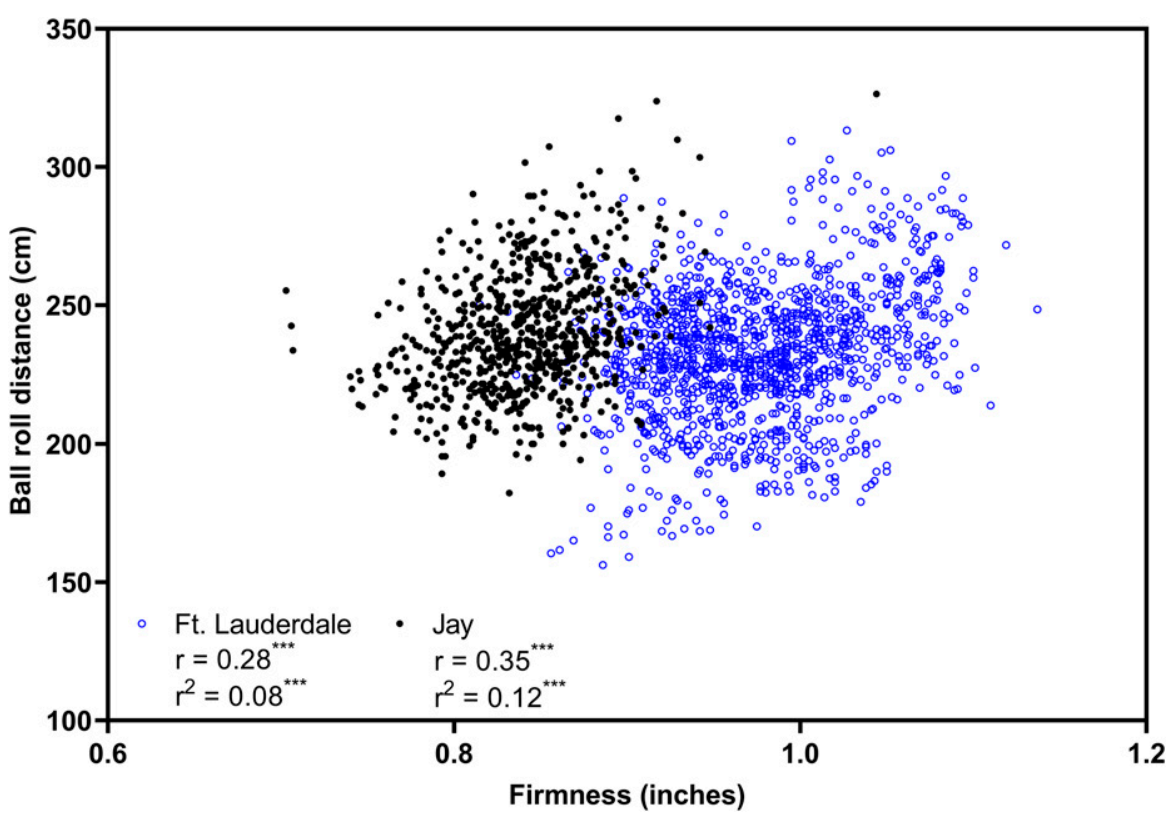

Fig. 2. Relationship between putting green surface firmness and ball roll distance of 'TifEagle' hybrid bermudagrass at Ft. Lauderdale, FL $(n=1279)$ and Jay, FL $(\mathbf{n}=704)$. Data points are raw data. ${ }^{* *}$ Correlation significant at $P<0.001 ; 1$ inch $=25.4 \mathrm{~mm}, 1 \mathrm{~cm}=0.3937$ inch .

Model residuals were analyzed for normality both numerically and graphically with the Shapiro-Wilk W test. Data were also checked graphically for homogeneity of variance. These tests determined data residuals within each location and month were distributed normally. The procedure GLIMMIX (SAS version 9.4; SAS Institute, Cary, NC) was used to analyze data, and mean separations were conducted using the TukeyKramer procedure for multiple comparisons $(P \leq 0.05)$. Correlation was conducted with raw data within each location using GraphPad Prism software (version 8.1; GraphPad Software, San Diego, CA) to compute the Pearson correlation coefficients.

\section{Results}

Precipitation was similar to the 15-year average, with three exceptions, as shown in Fig. 1. During May in Ft. Lauderdale, precipitation exceeded the 15 -year average by 2.5 fold, and in September and December in Jay, precipitation exceeded the 15 -year average by $\approx 3$-fold. Soil chemical analysis of the putting green root zones is shown in Table 2 . Chemical analysis indicated that $\mathrm{P}$ in Jay, and $\mathrm{P}$ and $\mathrm{K}$ in both locations were less than recommended (Florida Department of Environmental Protection, 2012). However, $\mathrm{P}$ and $\mathrm{K}$ soil levels did not result in an observed turfgrass deficiency symptoms.

In Ft. Lauderdale, wetting agents resulted in similar VWC as untreated turfgrass during 8 months; some wetting agents reduced VWC during the remaining 4 months, as shown in Table 3. In February, Fleet, Hydro90 , and Revolution resulted in a $10 \%$ reduction in VWC compared with untreated turfgrass. In September, Aqua-Aid, Fleet, Revolution, and Symphony resulted in a $14 \%$ reduction in VWC relative to untreated turfgrass. In November, Fleet and Symphony resulted in a $15 \%$ reduction and, in December, resulted in a $10 \%$ reduction in VWC compared with untreated turfgrass. The reduction in VWC did not result in a corresponding change in surface firmness or ball roll distance. Wetting agents resulted in similar firmness and ball roll distance relative to each other and untreated turfgrass during each month.

During 5 of the 6 months of the Jay study, wetting agents resulted in similar VWC as untreated turfgrass, as shown in Table 4. However, during October, Lesco-Wet resulted in a $12 \%$ reduction in VWC compared with untreated turfgrass. Similar to Ft. Lauderdale, this reduction in VWC was not concomitant with a change in firmness or ball roll distance. Wetting agents resulted in similar firmness compared with untreated turfgrass during June, July, August, and September. Symphony resulted in a $5 \%$ and $8 \%$ reduction in firmness compared with untreated turfgrass during October and December, respectively.

Ball roll distance was unaffected by wetting agents during each month in Jay. Correlation of firmness and ball roll distance resulted in a significant $(P<0.001)$ positive relationship in Jay and Ft. Lauderdale, as shown in Fig. 2. However, the substantial variation in ball roll distance resulted in coefficients of determination of 0.12 and 0.08 in Jay and Ft. Lauderdale, respectively. Correlation of VWC with ball roll distance and firmness resulted in highly significant $(P<$ $0.001)$ relationships in Jay and in Ft. Lauderdale, as shown in Fig. 3.

\section{Discussion}

Wetting agents did not influence VWC during the majority of months in Jay and Ft. Lauderdale; during the remaining months, wetting agents led to a $10 \%$ to $15 \%$ reduction in VWC compared with untreated turfgrass. Numerous studies have reported that wetting agents do not influence VWC on putting greens unless moisture is deficient. Lyons et al. (2009) investigated the influence wetting agents on a 80:20 (sand:peat) putting green in Ontario and reported wetting agents resulted in similar VWC as untreated turfgrass. They postulated that the lack of difference may have been the result of a lack of localized dry spots. Bauer et al. (2017) also documented that wetting agents did not influence VWC when conditions did not favor water repellency. Similarly, Soldat et al. (2010) reported wetting agents resulted in similar VWC compared with a reduced-irrigation control. However, they did report that wetting agents led to a reduction in VWC compared with a well-irrigated control. In our study, the untreated turfgrass was also well-irrigated and the results support those reported by Soldat et al. (2010). Thus, these results indicate that wetting agents applied to turfgrass maintained under sufficient irrigation may provide little benefit.

When wetting agents influenced VWC, VWC was reduced compared with untreated turfgrass. No increase in VWC relative to untreated turfgrass 
A

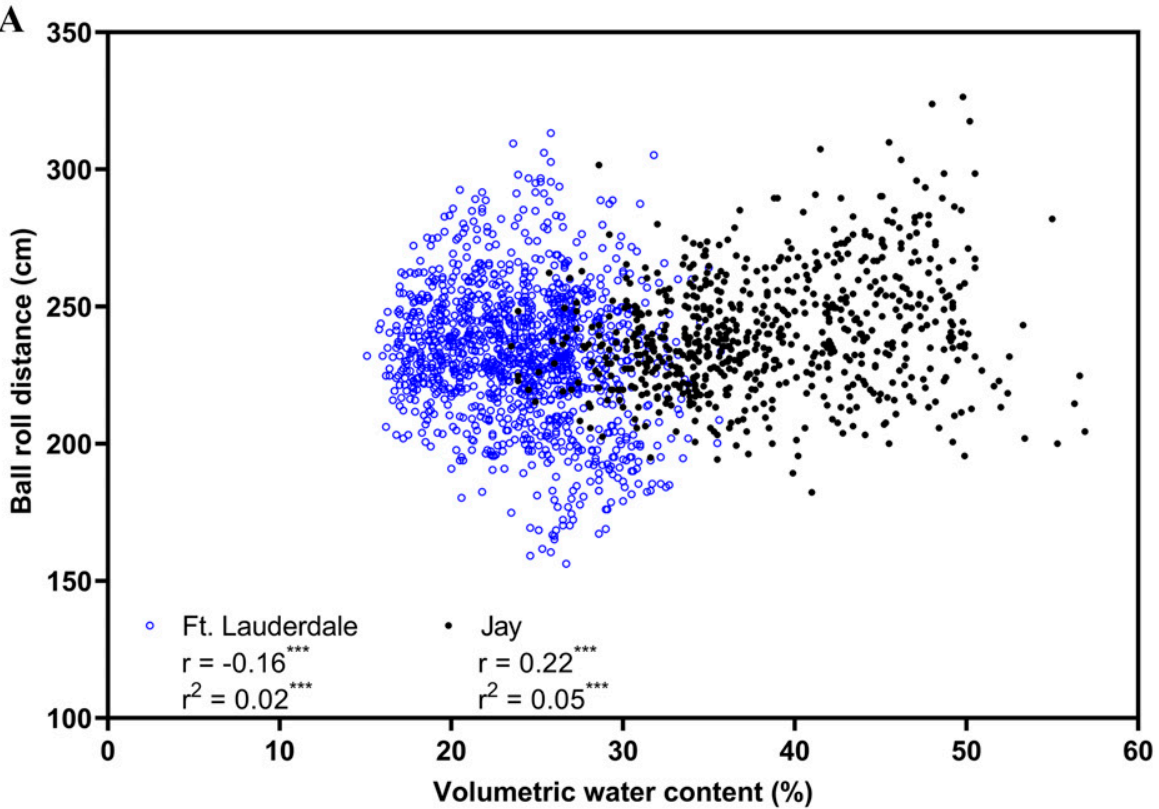

B

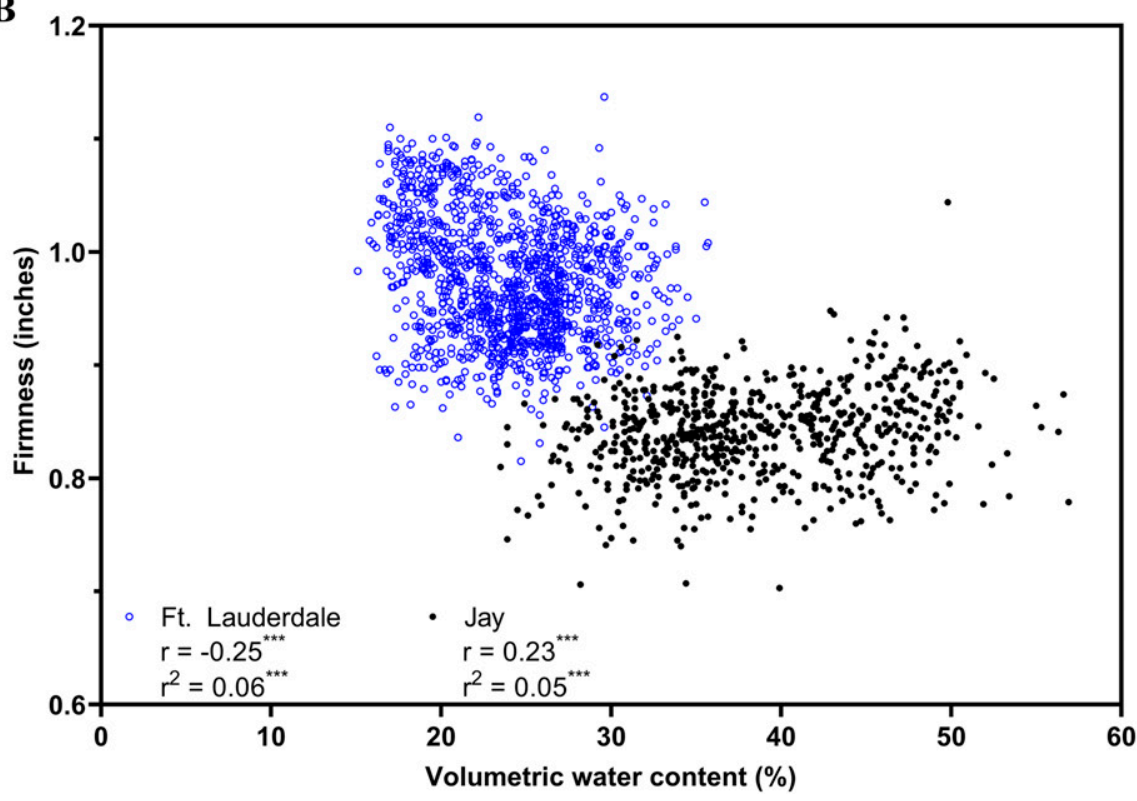

Fig. 3. Relationship between volumetric water content and (A) ball roll distance and $(B)$ putting green surface firmness of 'TifEagle' hybrid bermudagrass at Ft. Lauderdale, FL $(n=1279)$ and Jay, FL $(n=704)$. Data points are raw data. * * Correlation significant at $P<0.001 ; 1 \mathrm{~cm}=0.3937 \mathrm{inch}, 1 \mathrm{inch}=25.4 \mathrm{~mm}$.

was measured. These results contradict claims that wetting agents may increase the water holding capacity at the surface $[1.5$ inches $(3.81 \mathrm{~cm})$ in our study] compared with untreated turfgrass. Similarly, Leinauer and Sallenave (2001) reported wetting agents did not increase VWC in the top $5 \mathrm{~cm}$ of sand columns treated with three wetting agents. However when they measured VWC at depths of 15 and $25 \mathrm{~cm}$, wetting agents led to an increase in VWC compared with untreated turfgrass. These results suggest that, regardless of wetting agent chemistry, when wetting agents are applied to sandbased putting greens, VWC in the top 1.5 inches will either remain unaffected or will decline.

Surface firmness was unaffected by wetting agents in Ft. Lauderdale and during 4 of the 6 months in Jay compared with untreated turfgrass. The differing results between Jay and Ft. Lauderdale may have been a result of the age of the putting greens and/or the original construction of the sand:peat blend. The Ft. Lauderdale putting green was planted in 2016, whereas the Jay putting green had been established for more than 5 years. The greater age of the Jay putting green likely resulted in additional thatch, which resulted in a softer surface, as shown in Fig. 2. In addition, topdressing and aerification was conducted only once in Jay, which is considered minimal and may have contributed to the softer surface. We postulate that the softer surface in Jay may have resulted in greater variation than the firmer surface in Ft. Lauderdale and likely provided a greater probability of determining differences between treatments. Furthermore, thatch has been reported to bind wetting agents, preventing them from moving into the soil and resulting in the soil drying more slowly (Karnok et al., 2004). This postulate was also provided by Bauer et al. (2017), who reported no firmness differences among wetting agents during the first year, but measured firmness differences during the second year.

Ball roll distance did not increase as a result of wetting agents during any month. This result is supported by the corresponding lack of influence wetting agents had on surface firmness. Although VWC was documented to decline as a result of certain wetting agents during some months, surface firmness did not increase during any month. With no increase in surface firmness, it is not surprising that wetting agents did not increase ball roll distance.

Surface firmness and ball roll distance were found to have a highly significant, yet weak relationship. This indicates that a relationship between surface firmness and ball roll distance exists, but providing a prediction of ball roll distance based upon surface firmness is not possible because of the amount of variability. This result confirms that management practices known to increase surface firmness will likely increase ball roll distance, but the extent is unknown. The negative correlation coefficient between VWC and surface firmness, and VWC and ball roll distance in Ft. Lauderdale indicates that, as VWC increases in the top 1.5 inches, surface firmness and ball roll 
distance decrease. A plausible explanation for this is that the increased water at the putting green surface results in a softer surface, which in turn results in greater friction on the ball. These results were not observed in Jay. Although the relationship between VWC with ball roll distance and firmness in Jay was significant, the correlation coefficients were positive. The exact cause of this discrepancy between Jay and Ft. Lauderdale is unknown. However, the discrepancy may be a result of the age of the putting greens and the resulting thatch differences that may have occurred. Further research that includes ball roll distance may provide more practical information to golf course superintendents.

\section{Conclusions}

We reject the null hypothesis that wetting agents do not influence VWC and conclude that wetting agents do influence VWC of sandbased putting greens. The influence of wetting agents on VWC was inconsistent throughout the year in Jay and Ft. Lauderdale, but when VWC was influenced, VWC declined relative to untreated turfgrass. We fail to reject the null hypothesis that wetting agents increase surface firmness of sand-based putting greens. Inversely, surface firmness was reduced during October and November in Jay as a result of Symphony. However, the majority of evidence indicates wetting agents do not influence putting green surface firmness, at least under the conditions of our study. We fail to reject the null hypothesis that wetting agents do not influence ball roll distance on sand-based putting greens. This study found no evidence that wetting agents increase ball roll distance on sand-based 'TifEagle' hybrid bermudagrass putting greens.

\section{Literature cited}

Aamlid, T.S., T. Espevig, and A. Kvalbein. 2009. The potential of a surfactant to restore turfgrass quality on a severely water-repellent golf green. Biologia 64:620-623.

Baker, S.W., P.D. Hind, T.A. Lodge, J.A. Hunt, and D.J. Binns. 1996. Survey of golf greens in Great Britain: IV. Playing quality. J. Sports Turf Res. Inst. 72:9-24.

Bauer, S.J., M.J. Cavanaugh, and B.P. Horgan. 2017. Wetting agent influence on putting green surface firmness. Intl. Turfgrass Soc. Res. J. 13:624-628.

Carrow, R.N. 1995. Drought resistance aspects of turfgrasses in the Southeast: Evapotranspiration and crop coefficients. Crop Sci. 35:1685-1690.

Cisar, J.L., K.E. Williams, H.E. Vivas, and J.J. Haydu. 2000. The occurrence and alleviation by surfactants of soil-water repellency on sand-based turfgrass systems. J. Hydrol. 231:352-358.

Florida Department of Environmental Protection. 2012. Best management practices for the enhancement of environmental quality on Florida golf courses. Florida Department of Environmental Protection, Tallahassee, FL.

Karnok, K.J., K. Xia, and K.A. Tucker. 2004. Wetting agents: What are they, and how do they work? A better understanding of how wetting agents work will leads to their more effective use on the golf course. Golf Course Mgt. 72:84-86.

Kostka, S.J., L.W. Dekker, K. Oostindie, K. Mauser, and M.K. Franklin. 2008. May surfactants affect more than wetting in water repellent soils? Eur. Turf. Soc. Conf. Proc 1:109-110.

Leinauer, B. and R.M. Sallenave. 2001. Effects of soil surfactants on water retention in turfgrass rootzones. Intl. Turfgrass Soc. Res. J. 9:542-547.

Linde, D.T., L.J. Stowell, W. Gelernter, and K. McAuliffe. 2011. Monitoring and managing putting green firmness on golf courses. Appl. Turf. Sci. doi: 10.1094/ ATS-2011-0126-01-RS.
Lyons, E.M., K.S. Jordan, and K. Carey. 2009. Use of wetting agents to relieve hydrophobicity in sand rootzone putting greens in a temperate climate zone. Intl. Turfgrass Soc. Res. J. 11:1131-1138.

McCarty, L.B. 2016. Applied soil physical properties, drainage, and irrigation strategies. Springer, New York, NY.

Mehlich, A. 1984. Mehlich 3 soil test extractant: A modification of Mehlich 2 extractant. Commun. Soil Sci. Plant Anal. 15:1409-1416.

Munoz, M. 2016. Advice for spring wetting agent programmes. 22 July 2017. <http://golfbusinessnews.com/news/ management-topics/advice-for-springwetting-agent-programmes $>$.

Nelson, D.W. and L.E. Sommers. 1996. Total carbon, organic carbon, and organic matter, p. 961-1010. In: D.L. Sparks (ed.). Methods of soil analysis: Part 3. American Society of Agronomy, Soil Science Society of America, Madison, WI.

Schiavon, M., B. Leinauer, M. Serena, B. Maier, and R. Sallenave. 2014. Plant growth regulator and soil surfactants' effects on saline and deficit irrigated warmseason grasses: I. Turf quality and soil moisture. Crop Sci. 54:2815-2826.

Soldat, D.J., B. Lowery, and W.R. Kussow. 2010. Surfactants increase uniformity of soil water content and reduce water repellency on sand-based golf putting greens. Soil Sci. 175:111-117.

University of Florida. 2020. Florida automated weather network. 2 Mar. 2020. $<$ https://fawn.ifas.ufl.edu>.

U.S. Department of Agriculture. 2004. Soil survey laboratory methods manual. Soil Survey Investigations Rep. 42. U.S. Department of Agriculture, Soil Conservation Service, Washington, DC.

U.S. Golf Association. 2018. USGA recommendations for a method of putting green construction. 2 Feb. 2020. <http://archive. lib.msu.edu/tic/usgamisc/monos/ 2018recommendationsmethodputtinggreen. pdf>. 